\title{
Lessons From the COVID-19 Pandemic
}

\author{
Anggi Cecilia Safaningrum \& Adib Rifqi Setiawan
}

We do not know when the Covid-19 pandemic will end; we do not know how it will end; and, at present, we can only speculate about its long-term political and economic impact. In a time of crisis, we are infected with uncertainty. But there at least seven things that make this crisis very different from previous ones.

The first lesson is that, unlike the 2008-2009 financial crisis, the coronavirus will force the return of big government. After the collapse of Lehman Brothers, many observers believed that crisis-born mistrust in the market would lead to greater faith in the government. This concept was nothing new: in 1929, following the onset of the Great Depression, people demanded strong government intervention to offset the failings of the market. In the 1970s, it was the other way around: people were disappointed with government intervention, so they started to believe in the market again. The paradox of 2008-2009 is that mistrust in the market did not lead to demand for greater government intervention. Now, the coronavirus will bring the government back in a big way. People rely on the government to organise a collective defence against the pandemic, and they rely on the government to save a sinking economy. The effectiveness of governments is now measured by their capacity to change people's everyday behaviour.

The second lesson of the coronavirus relates to trust in expertise. The financial crisis and the 2015 refugee crisis generated a great deal of popular discontent with experts. This shift, which has been one of the major successes of populists politicians in the past ten years, will be reversed by the coronavirus. Most people are very open to trusting experts and heeding the science when their own lives are at stake. One can already see the growing legitimacy that this has lent to the professionals who lead the fight against the virus. Professionalism is back in fashion.

The third lesson is open to interpretation but very important nonetheless. Unfortunately, the coronavirus could increase the appeal of the big data authoritarianism employed by the Chinese government. One can blame Chinese leaders for the lack of transparency that made them react slowly to the spread of the virus, but the efficiency of their response and the Chinese state's capacity to control the movement and behaviour of people has been impressive. In the current crisis, citizens constantly compare the responses and effectiveness of their governments with those of other governments. And we should not be surprised if, the day after the crisis, China looks like a winner and the United States looks like a loser.

The fourth lesson concerns crisis management. What governments learned in dealing with economic crises, the refugee crisis, and terrorist attacks was that panic was their worst enemy. If, for months after a terrorist attack, people changed their everyday behaviour and stopped leaving their houses, this would help terrorists achieve their goals. The same was true in 2008-2009: a change in behaviour often increased the costs of the crisis. So, leaders and citizens responded with messages to "stay calm", "get on with life", "ignore the risk", and "don't exaggerate". Now, governments have to tell citizens to change their behaviour by staying at home. And governments' success in this very much depends on their capacity to scare people into doing as instructed. "Do not panic" is the wrong message for the Covid-19 crisis. To contain the pandemic, people should panic - and they should drastically change their way of living.

The fifth lesson is that the Covid-19 crisis will have a strong impact on intergenerational dynamics. In the context of debates about climate change and the risk it presents, younger generations have been very critical of their elders for being selfish and not thinking about the future seriously. The coronavirus reverses these dynamics: now, the older members of society are much more vulnerable and feel threatened by millennials' visible unwillingness to change their way of living. This intergenerational conflict could intensify if the crisis lasts for a long time.

The sixth lesson is that, at a certain point, governments will be forced to choose between containing the spread of the pandemic at the cost of destroying the economy or tolerating a higher human cost to save the economy.

The seventh lesson is that the coronavirus will strengthen nationalism, albeit not ethnic nationalism. To survive, the government will ask citizens to erect walls not simply between states but between individuals, as the danger of being infected comes from the people they meet most often. It is not the stranger but those closest to you who present the greatest risk.

It is still very early days in speculating about the political impact of Covid-19. The crisis has justified the fears of the antiglobalists: closed airports and the self-isolated individuals appear to be the ground zero of globalisation. But, paradoxically, the new anti-globalist moment could weaken populist political actors who, even when they have a point, do not have a solution. The Covid-19 crisis will also dramatically reshape the EU's response to all other crises it has faced in the last decade. Fiscal discipline is no longer the economic mantra even in Berlin, and there is no European government that, at the present moment, will advocate for opening borders to refugees.

It remains to be seen how exactly the crisis will affect our future. But it is clear that, in all, the coronavirus will call into question some of the basic assumptions on which the state is founded. 